\title{
Bioequivalence study of four different trademarks of enalapril maleate in spontaneously hypertensive rats ${ }^{1}$
}

\author{
Estudo da bioequivalência de quatro diferentes marcas comerciais de maleato de \\ enalapril em ratos espontaneamente hipertensos
}

\author{
Nilo César do Vale Baracho, Guilherme D’Andréa Saba Arruda", Lidinei José Alves ${ }^{I I}$, Márcio Felipe Salomon \\ Carneiro ${ }^{\mathrm{II}}$, Matheus Teodoro Grilo Siqueira ${ }^{\mathrm{II}}$, Héctor Gustavo Arango ${ }^{\mathrm{III}}$, José Marcos dos Reis ${ }^{\mathrm{IV}}$ \\ ${ }^{\mathrm{I}}$ Master, Associate Professor of Pharmacology and Biochemistry, FMIt, Minas Gerais, Brazil. \\ ${ }^{\text {II }}$ Graduate student, FMIt, Minas Gerais, Brazil. \\ III PhD, Professor of Biostatistics, FMIt, Minas Gerais, Brazil. \\ IV Associate Professor, Anatomy and Surgical Techniques, FMIt, Minas Gerais, Brazil.
}

\begin{abstract}
Introduction: High blood pressure is a systemic disease which has major clinical and psycho-social repercussions, involves a high morbidity-mortality rate and generates high costs for the health system. Its treatment involves the use of antihypertensive drugs, which are commercialized as trademark, generic or similar drugs. Purpose: To verify the antihypertensive effect produced by a similar dose of different trademarks of enalapril maleate in spontaneously hypertensive rats (SHR). Methods: Fifteen $\mathrm{mg} / \mathrm{kg}$ of enalapril maleate were administered by gavage in 50 SHR rats and their blood pressure was verified through tail plethysmography every three days in a period of 16 days. Results: The group treated with reference drug has shown a significant reduction on blood pressure levels when compared to the control group. Thus, treatments with enalapril maleate of generic, similar-A and similar-B brands have also shown significant reduction on animals' blood pressure. Conclusion: The use of generic drug and similars (A and B) drugs in the same doses and for the same period of time has not shown significant difference regarding the reference drug, which suggests that the brands tested are bioequivalent.
\end{abstract}

Key words: Hypertension. Drugs, Generic. Therapeutic Equivalency. Rats.

\section{RESUMO}

Introdução: A hipertensão arterial é uma doença sistêmica que traz grandes repercussões clínicas e psico-sociais, cursa com uma elevada morbi-mortalidade e gera elevados gastos para o sistema de saúde. Seu tratamento envolve a utilização de fármacos anti-hipertensivos, os quais são comercializados como remédios de marca, genéricos ou similares. Purpose: Verificar o efeito anti-hipertensivo produzido por dose igualitária de diferentes marcas de maleato de enalapril, em ratos naturalmente hipertensos. Métodos: Foram administrados, por meio de gavagem, $15 \mathrm{mg} / \mathrm{kg}$ de maleato de enalapril em 50 ratos naturalmente hipertensos e verificada a pressão arterial, através de pletismografia de cauda, a cada três dias, em um período de 16 dias. Resultados: O grupo testado com o fármaco de referência mostrou uma redução significativa dos níveis pressóricos quando comparado ao grupo controle. Da mesma forma, o tratamento com Maleato de Enalapril da marca genérica e das marcas similar-A e similar-B também produziu redução significativa da pressão arterial dos animais. Conclusão: A utilização do medicamento genérico e os similares A e B nas doses utilizadas e no tempo de experimentação adotado, não indicou diferença significativa em relação ao fármaco de referência, sugerindo que as marcas testadas são bioequivalentes.

Descritores: Hipertensão. Medicamentos Genéricos. Equivalência Terapêutica. Ratos. 


\section{Introduction}

High blood pressure is a systemic disease with a high prevalence in Brazil, with indices ranging from $22.3 \%$ to $43.9 \%$ depending on the sample used. Thus, it has major repercussions both on clinical and psycho-social points of view. This is due to the fact that rising blood pressure is an independent risk factor for cardiovascular disease..$^{1,2}$

This clinical entity presents a series of high morbidity-mortality complications such as cerebrovascular disease, coronary artery disease, heart failure, chronic renal failure and extremity vascular disease. All of these complications imply in high rates of hospital stay (1.180.184) in 2005, with a high cost to Sistema Único de Saúde (SUS) of about $\mathrm{R} \$ 1,323,775,008.28$ in the same year. ${ }^{1,2,3}$

This disease is still related to a high mortality rate with $27.4 \%$ of deaths from cardiovascular diseases in 2003, and with cerebrovascular disease as the major cause of death mainly in females. Another datum that corroborates with mortality rates is that high blood pressure accounts for $40 \%$ of deaths from stroke and $25 \%$ of those from coronary disease. ${ }^{2,4}$

It is important to highlight that there are several risk factors for high blood pressure, such as: obesity, ethylism, sedentarism, socioeconomic factors, smoking, aging and ethnicity. Therefore, the treatment involves reducing these risk factors and most of the times the use of drugs in order to reduce high blood pressure, which are directly proportional to mortality rate. ${ }^{2,3}$

Drug-therapy approach involves the use of a series of drug classes (diuretics, angiotensin-converting enzyme inhibitors, calcium channel blockers, beta blockers, adrenergic inhibitors, AT receptor blockers) often requires drug association, which makes the treatment expensive in economic terms and with higher risks of side effects. Thus, it is possible to notice high costs involving treatment of hypertension as well as several other chronic diseases such as diabetes mellitus, rheumatologic diseases, both for the patient and for SUS. ${ }^{2,3}$

In this context, the law number 9,787 from 1999 regulated and standardized the sales of drugs termed generic in Brazil with the purpose of providing a better access of the population to chronic drugs, contributing to therapeutic success. This legal term describes a commercial preparation with the pharmacological name of the drug with the same dose, presentation and administration route of the reference drug. Generic drugs have already been used in the United States and in several countries in Europe since the 1960s and they represent over $70 \%$ of the drugs sold in the USA. ${ }^{5}$

In order to register this new class of drugs at "Agência Nacional de Vigilância Sanitária" (ANVISA), they should meet technical criteria (required by the legislation), and they should fulfill some property requirements, such as drugs which solve most health problems of the population; expensive drugs/treatment; continuous drugs, and primary health care drugs. ${ }^{5}$

There are still similar drugs which have the same active ingredient as the reference drug and which have a different fantasy name. They usually cost less but there are exceptions. "Agência Nacional de Vigilância Sanitária"
(ANVISA) is responsible to control them, however, it is a very poor control as for technical issues regarding bioavailability.

Bioequivalence is defined as a comparative study between bioavailability of two drugs which have the same indications, administration route and dose. Thus, generic drugs should offer the same guarantee of safety and effectiveness as the original drugs, which is why they are submitted to the same quality rules. They are assessed through three pharmacokinetic parameters: plasmatic concentration area curve, maximum blood concentration and maximum time required to reach maximum concentration. ${ }^{6,7}$

Thus, due to uncertainties concerning the bioavailability of similar and generic drugs, the present study aims at verifying the antihypertensive effect produced by the same dose of different trademarks commercialized of enalapril maleate, in spontaneously hypertensive rats-SHR.

\section{Methods}

The study was carried out at Biochemistry and Pharmacology Laboratories of "Faculdade de Medicina de Itajubá" (FMIt), following the recommendations of COBEA (Colégio Brasileiro de Experimentação Animal) (Brazilian College of Animal Experimentation), norms of the federal law n 6,638 and CIOMS (Council for International Organization of Medical Science).

For this study, 50 young adult male spontaneously hypertensive rats SHR, with their weight varying from 220 and $300 \mathrm{~g}$ and aging from sixty to ninety days, from the breeding facilities of Faculdade de Medicina de Itajubá. Animals were randomly divided in five groups with ten rats in each group, and a total of fifty rats $(n=50) .{ }^{8}$ (Table 1)

The sample was used based on the replication method, i.e. using another study published in the medical literature making some changes as for the disposition of the groups tested. ${ }^{8}$

TABLE 1 - Experimental Design

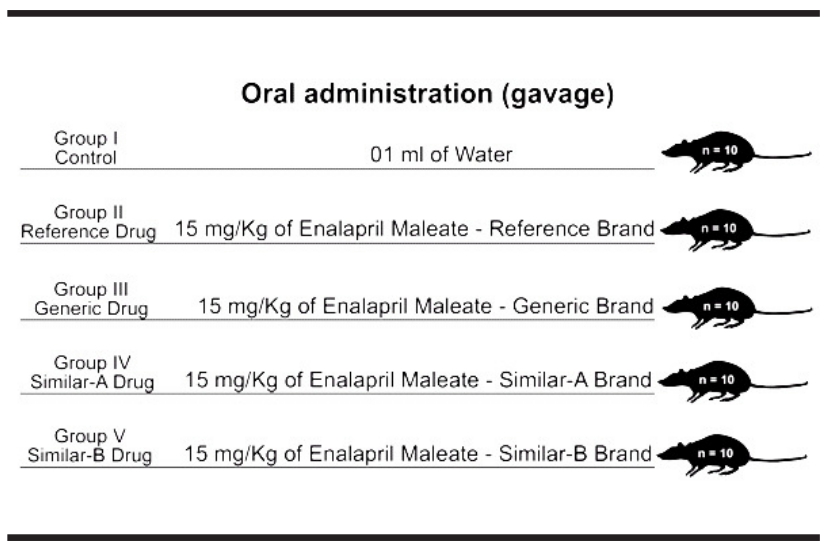

Animals were kept in individual cages with water and chow ad libitum and submitted to 12-hour light-dark cycles. The first day of experiment corresponded to the animals' adaptation to the new habitat, so that the change of location would not influence on the data obtained, and 
they did not receive any treatment during this period.

On the fifteen following days, rats were treated through a single dose of the active ingredient, enalapril maleate, administered orally (gavage) to groups II, III, IV and $\mathrm{V}$, and water to group I, in the morning. Blood pressure was measured in the afternoon, always at the same time, every three days, by means of tail plethysmography.

During the experiment, three animals died, one from group I, one from group II and one from group III, and they were not replaced.

All drugs were prepared the same way, starting by breaking the tablets, followed by diluting them in distilled water, obtaining a solution of $05 \mathrm{mg} / \mathrm{ml}$. It is important to highlight that this solution was prepared daily, thus preventing any degradation process of the active ingredient.

Arterial pressure was measured indirectly through a non-invasive system (tail plethysmography) when animals were awake. This system uses a tail cuff coupled to a mercury column. ${ }^{9,10,11}$ In order to optimize the process, rats were restrained and placed in an incubator for five minutes with a 100W incandescent lamp, previously heated for thirty minutes.

In order to compare experimental groups, statistical distribution of data obtained was tested regarding normality standard. With this purpose, Kolmogorov-Smirnov (K-S) normality test was applied. Data referring to pressure levels rejected the hypothesis of normality $(p<0.01)$. Thus, groups were compared through a non-parametric analysis, using Kruskal-Wallis test (H test) which allows comparing multiple groups. As for group analysis regarding the drugs tested on different days of experiment, i.e., on days D1, D4, D7, D10, D13 and D16 values of rats arterial pressure confirm the hypothesis of normality by the Kolmogorov-Smirnov $(\mathrm{K}-\mathrm{S})$ test - $(p>0.05)$. Thus, data were compared through ANOVA followed by Tukey test.

The statistical decision criterion was: in cases where $p$ was less than 0.05 , statistics was considered significant. For $p$ between 0.05 and 0.10 , it was referred as a trend to significance.

\section{Results}

The group treated with reference drug at a dose of $15 \mathrm{mg} / \mathrm{kg}$ of weight has shown a significant decrease in blood pressure levels when compared to the control group, (Control vs Reference drug: $167.57 \mathrm{mmHg} \pm 3.71$ vs $124.44 \pm$ $3.71 p<0.01)$.

Continuous treatment with enalapril maleate of the generic drug at a dose of $15 \mathrm{mg} / \mathrm{kg}$ of weight has also shown a decrease on arterial pressure levels (Control vs Sandoz: $167.57 \mathrm{mmHg} \pm 3.71$ vs $130.98 \pm 3.71 p<0.01)$.

As the other drugs, the administration of similar-A drug and similar-B drug, both at a dose of $15 \mathrm{mg} / \mathrm{kg}$, has resulted in a decrease of arterial pressure levels in rats (Control vs Similar-A drug: $167.57 \mathrm{mmHg} \pm 3.71$ vs $131.38 \pm$ $3.52 p<0.01$ and Control vs Similar-B drug: $167.57 \mathrm{mmHg} \pm$ 3.71 vs $131.56 \pm 3.52 p<0.01)$.

TABLE 2 - Data referring to means, standard deviations, confidence intervals and sample of arteral pressure (AP-mmHg) of the groups tested

\begin{tabular}{llllll}
\hline Group & $\begin{array}{c}\text { Mean PA } \\
\text { (mmHg) }\end{array}$ & $\begin{array}{c}\text { Standard error } \\
\text { Arterial pressure }\end{array}$ & $\begin{array}{c}\text { Arterial } \\
\text { pressure+95.00\% }\end{array}$ & $\begin{array}{c}\text { Arterial } \\
\text { pressure+95.00\% }\end{array}$ & Sample (n) \\
\cline { 2 - 5 } Control & 167.57 & 3.71 & 160.25 & 174.89 & $54^{*}$ \\
Reference drug & 124.44 & 3.71 & 117.12 & 131.76 & $54^{*}$ \\
Generic drug & 130.98 & 3.71 & 123.65 & 138.30 & $54^{*}$ \\
Similar-A drug & 131.38 & 3.52 & 124.43 & 138.33 & 60 \\
Similar-B drug & 131.56 & 3.52 & 124.61 & 138.51 & 60 \\
\hline
\end{tabular}

*Note: Due to the loss of animals during the experimental period.

Values referring to means, standard errors and

confidence intervals regarding arterial pressure of several groups tested are represented in Figure 1.

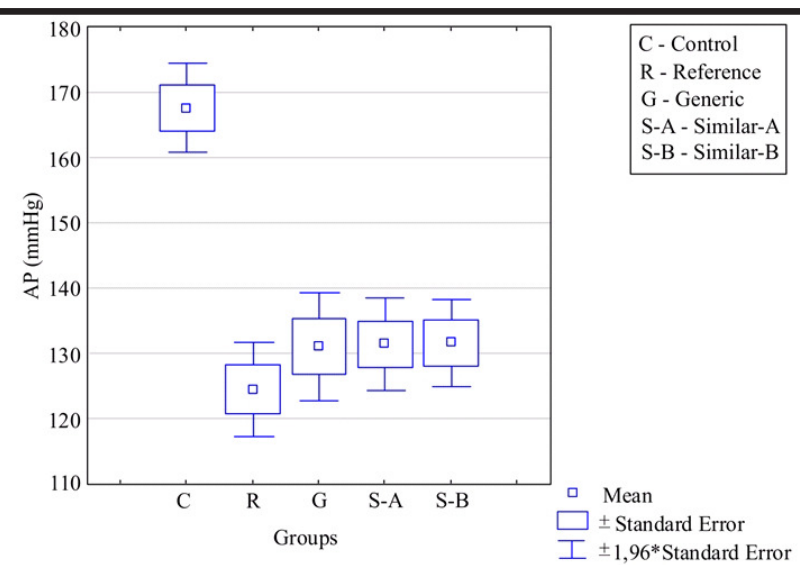

FIGURE 1 - Graphic representation of means, standard and confidence intervals regarding arterial pressure ( $\mathrm{mmHg}$ ) of several groups tested. (Control, Reference drug, Generic drug, Similar-A drug and Similar-B drug) 
Therefore, treatment with reference drug, generic drug, similar-A drug or similar-B drug produced a significant effect reducing pressure levels on all days tested D4, D7, D10, D13 and D16, when compared to the control group. The additional datum is that all drugs produced a similar effect with no significant differences among the several drugs tested (Tables 3, 4, 5, 6 and 7). The same effect occurred the similarly every time rats arterial pressure was measured $(p>0.05)$.

TABLE 3 - Values of $p$ among groups tested during the experiment for D4

\begin{tabular}{lllll}
\hline GROUPS & Reference drug & Generic drug & Similar-A drug & Similar-B drug \\
Control & 0.0066 & 0.0083 & 0.0024 & 0.0112 \\
Reference drug & & 0.9999 & 0.9990 & 0.9985 \\
Generic drug & & & 0.9969 & 0.9996 \\
Similar-A drug & & & & 0.9803 \\
\hline
\end{tabular}

Note: numbers in bold show a significant difference.

TABLE 4 - Values of $p$ among groups tested during the experiment for D7

\begin{tabular}{lllll}
\hline GROUPS & Reference drug & Generic drug & Similar-A drug & Similar-B drug \\
Control & 0,0014 & 0,0402 & 0,0122 & 0,0004 \\
Reference drug & & 0,7315 & 0,9025 & 0,9978 \\
Generic drug & & & 0,9951 & 0,5171 \\
Similar-A drug & & & & 0,7351 \\
\hline
\end{tabular}

Note: numbers in bold show a significant difference.

TABLE 5 - Values of $p$ among groups tested during the experiment for D10

\begin{tabular}{lllll}
\hline GROUPS & Reference drug & Generic drug & Similar-A drug & Similar-B drug \\
Control & 0,0001 & 0,0001 & 0,0010 & 0,0041 \\
Reference drug & & 0,9928 & 0,3135 & 0,1302 \\
Generic drug & & & 0,5684 & 0,2932 \\
Similar-A drug & & & 0,9875 \\
\hline
\end{tabular}

Note: numbers in bold show a significant difference.

TABLE 6 - Values of $p$ among groups tested during the experiment for D13

\begin{tabular}{lllll}
\hline GROUPS & Reference drug & Generic drug & Similar-A drug & Similar-B drug \\
Control & 0,00013 & 0,0012 & 0,0017 & 0,0012 \\
Reference drug & & 0,5206 & 0,3592 & 0,4340 \\
Generic drug & & & 0,9993 & 0,9999 \\
Similar-A drug & & & & 0,9999 \\
\hline
\end{tabular}

Note: numbers in bold show a significant difference.

TABLE 7 - Values of $p$ among groups tested during the experiment for D16

\begin{tabular}{lllll}
\hline GROUPS & Reference drug & Generic drug & Similar-A drug & Similar-B drug \\
Control & 0,0002 & 0,0003 & 0,0011 & 0,0001 \\
Reference drug & & 0,9999 & 0,9475 & 0,9994 \\
Generic drug & & & 0,9601 & 0,9986 \\
Similar-A drug & & & & 0,8601 \\
\hline
\end{tabular}




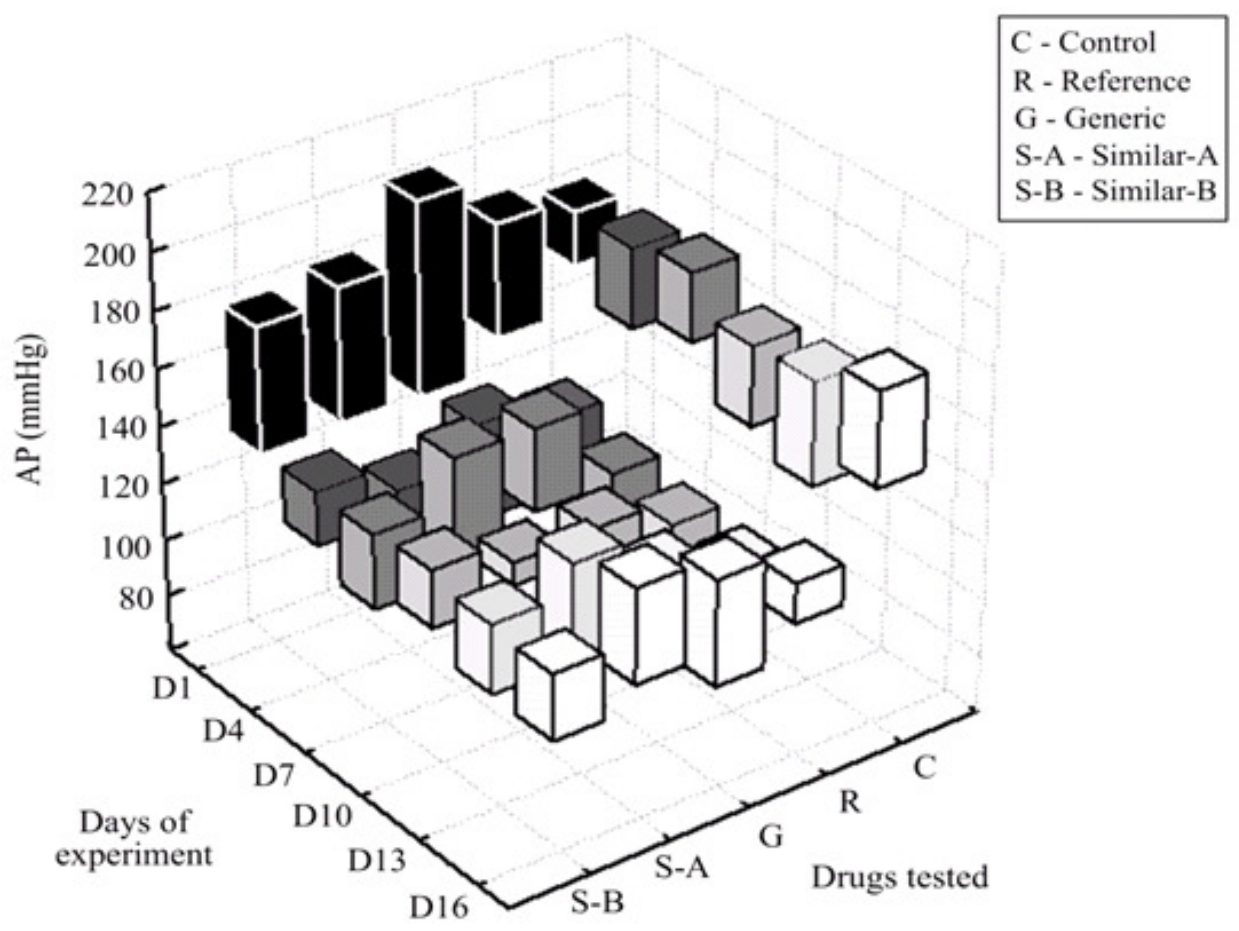

FIGURE 2 - Graphic representation of means regarding arterial pressure (mmHg) of several groups tested, evolutively during the experiment. (Control, Reference drug, Generic drug, Similar-A drug and Similar-B drug)

\section{Discussion}

Generic drugs were introduced in Brazil according to the law number 9,787 in 1999 and had the purpose to amplify the access of the population to drugs in the treatment of several chronic diseases. However, these drugs must be bioequivalent when compared to the reference drug in order to guarantee greater safety for patients. ${ }^{5,12}$

Having this in mind, several studies regarding bioequivalence among drugs have been carried out, when generic and similar drugs started to be commercialized in this country. In Brazil, as well as in the United States, the scientific community as well as the general population have been resistant as they have been unsure of the guarantees as for the effectiveness, as well as the safety and tolerability of these new drugs..$^{5,12,13}$

It is important to highlight that when generic drugs started to be implemented in Brazil, there was a large demand for generic drugs. This problem was solved with the use of drugs that had already been approved in other countries, with no need to test them in order to confirm their bioequivalence to the national reference drug when registering it. This has contributed to uncertainties about this group of drugs. ${ }^{5}$

Several studies, testing bioequivalence of azitromicin and sertraline in humans, verified that both absorption rate and extension were bioequivalent when generic drugs were compared to reference drugs. ${ }^{14,15}$ Another study, testing two formulations of cyclosporin
A, were similar in terms of renal effect when administered in rats. ${ }^{16}$

On the other hand, a review in the literature about psychoactive drugs has shown that the use of generic phenytoin provided a plasmatic level of $31 \%$ lower than the trademark drug. In addition, the use of carbamazepine in the generic formulation was associated with an increased incidence of recurrent convulsive crises when compared to the trademark drug. ${ }^{17}$

Another aspect analyzed in this review was regarding valproic acid, which had two formulations tested, with an increased incidence of severe epileptic crises with the generic drug, imposing a more detailed analysis carried out by FDA, which found differences between two formulations as for bioavailability. In the same study, they mentioned differences as for diazepam pharmacokinetics, showing advantages to the trademark drug related to the substances tested. ${ }^{17}$

Due to the questions brought about as for bioavailability, the present study brings results on the effectiveness of enalapril maleate. Data show that rats-SHR chronically treated with reference, generic and similar drugs decreased the arterial pressure significantly $(p<0.05)$ regarding the control group. However, there was no difference in the effects produced by generic and similar drugs, when compared to the reference drug when reducing particular blood pressure levels in rats, showing bioequivalence among all trademarks tested (Figure 1).

It is important to notice that the present study has 
had an evaluation method of bioequivalence, a clinical feature, and the arterial pressure measurement. The same methodological aspect was employed when convulsive crises largely recurred using generic anticonvulsive drugs. ${ }^{17}$ In a more punctual analysis, i.e. comparing the days when arterial pressure was measured (D4, D7, D10, D13, D16), it was verified that the effect produced was steady throughout the experiment, which allows us to infer that drugs reached a steady-state, a target which is searched for all drugs (Figure 2).

\section{Conclusion}

According to our new data, the use of the generic drug and the similar drugs of the in the doses used and in the time used in the experiment has shown to be bioequivalent regarding the reference drug.

\section{References}

1. Lewington S, Clarke R, Qizibash N, Peto R, Collins R. Age-specific relevance of usual blood pressure to vascular mortality: a metaanalysis of individual data for one million adults in 61 prospective studies. Lancet. 2002;360:1903-13.

2. Sociedade Brasileira de Cardiologia, Sociedade Brasileira de Hipertensão, Sociedade Brasileira de Nefrologia. V. Diretrizes brasileiras de hipertensão arterial. São Paulo: SBC; 2006.

3. The seventh report of the Joint National Committee on Prevention, Detection, Evaluation, and Treatment of High Blood Pressure. The JNC 7 Report. JAMA. 2003;289(19):2560-72.

4. Lotufo PA. Stroke in Brazil: a neglected disease. Sao Paulo Med J. 2005;123(1):3-4.

5. Dias CR, Romano-Lieber NS. Generic drug policy implementation in Brazil. Cad Saude Publica. 2006;22(8):1661-9.

6. Nightingale SL, Morrison JC. Generic drugs and the prescribing physician. JAMA. 1987 Sep 4;258(9):1200-4.

7. Chow SC, Liu J. Meta-analysis for bioequivalence review. J Biopharm Stat. 1997 Mar;7(1):97-111.

8. Rodriguez-Iturbe B, Quiroz Y, Ferrebuz A,
Parra G, Vaziri ND. Evolution of renal interstitial inflammation and NF-kappaB activation in spontaneously hypertensive rats. Am J Nephrol. 2004;24(6):587-94.

9. Zatz R. A low cost tail-cuff method for the estimation of mean arterial pressure in conscious rats. Lab Anim Sci. 1990;40(2):198201.

10. Kubota Y, Umegaki K, Kagota S, Tanaka N, Nakamura K, Kunitomo M, Shinozuka K. Evaluation of blood pressure measured by tailcuff methods (without heating) in spontaneously hypertensive rats. Biol Pharm Bull. 2006;29(8):1756-8.

11. Zintzaras E. Statistical aspects of bioequivalence testing between two medicinal products. Eur J Drug Metab Pharmacokinet. 2005;30(1-2):41-6.

12. Dighe SV. A review of the safety of generic drugs. Transplant Proc. 1999;31 (Suppl 3A): S23-24.

13. Verbeeck RK, Kanfer I, Walker RB. Generic substitution: the use of medicinal products containing different salts and implications for safety and efficacy. Eur J Pharm Sci. 2006;28(12):1-6.

14. Carmo GC, Martins FS, Quental DP, Santana GSM, Moraes MO, Moraes MEA, Frota Bezerra FA, Nucci G. Bioequivalência de duas formulações de azitromicina. In: XXXIV Congresso Brasileiro de Farmacologia e Terapêutica Experimental; 2002; Águas de Lindóia, São Paulo. Sociedade Brasileira de Farmacologia e Terapêutica Experimental; 2002. p. 219.

15. Mendes GD, Araujo MVF, Paris EG, BarrientosAstigarraga RE, Oliveira $\mathrm{CH}$. Biodisponibilidade comparativa de duas formulações de sertralina em voluntários humanos sadios após a administração de uma única dose. Rev Bras Med. 2004; 61(1/2):80-4.

16. Mendes GEF, Burdmann EA. Comparação da nefrotoxicidade experimental de duas formulações de microemulsão de ciclosporina A. J Bras Nefrol. 2002; 24(Supl 1): S18-25.

17. Borgheini G. The bioequivalence and therapeutic efficacy of generic versus brandname psychoactive drugs. Clin Ther. 2003;25(6):1578-92.

\section{Correspondence:}

José Marcos dos Reis

Conflict of interest: none

R. Tupi, 153

37502-456 Itajuba-MG Brazil

josem.reis@terra.com.br

Received: September 17, 2007

Review: November 19, 2007

Accepted: December 18, 2007

\section{How to cite this article}

Baracho NCV, Arruda GAS, Alves LJ, Carneiro MFS, Siqueira MTG, Arango HG, Reis JM. Bioequivalence study of four different trademarks of enalapril maleate in spontaneously hypertensive rats. Acta Cir Bras. [serial on the Internet] 2008 Mar-Apr;23(2). Available from URL: http://www.scielo.br/acb 